Vegetalika. 2017. 6(1): 1-11

\title{
Pengaruh Perendaman Air pada Benih Nangka (Artocarpus heterophyllus Lamk.) dengan Berbagai Posisi Tanam Benih terhadap Pertumbuhan Bibit
}

\section{Influence of Water Immersion on Seeds Jackfruit (Artocarpus heterophyllus Lamk.) by Various Positions Planting Seeds on Seedling Growth}

\author{
Asiyah Atdwiyani ${ }^{1)}$, Setyastuti Purwanti ${ }^{2 *}$, Sri Muhartini²) \\ 1) Program Studi Pemuliaan Tanaman, Fakultas Pertanian, Universitas Gadjah Mada \\ 2) Departemen Budidaya Pertanian, Fakultas Pertanian, Universitas Gadjah Mada \\ *) Penulis untuk korespodensi E-mail: setyastuti_purwanti@ugm.ac.id
}

\begin{abstract}
The jackfruit needs keep increasing for household comsumption, industry and plant conservation. This requires efforts to increase productivity through the development and maintenance of the plant that more intensive and efficient. An aspect to consider in efforts to increase productivity is the plant nursery. The experiment was ained to know the effect of soaking water of jackfruit seed (Artocarpus heterophyllus Lamk.) at various, this experiment was conducted at the Laboratory of Horticulture and WireHouse, Department of Agriculture, Faculty of Agriculture Gadjah Mada University Yogyakarta on February until July 2016. This experiment used $2 \times 5$ facrorial design and arranged in the completely randomized design (CRD) with three aplications. The first factor was soaking water of jackfruit seed consisted of P1 (soaked one day), P2 (soaked two days), P3 (without treatment / control), P4 (without soaked one day) and P5 (without soaked two days). The second factor was the position of seedling (hilum) that consists of T1 (stomach) and T2 (supine). Observations were made to force germination, vigor index and vigor index hypothetical. The results showed that there is no interaction between the immersion factor of the position of planting seed to growth. Jackfruit seeds were planted by the prone position gave the best growth quality. Jackfruit seed was soaked for one day gave the best effect on the growth of seedling.
\end{abstract}

Keyword : jackfruit seed, position of seddling, water soaking, germination, vigor index

\section{INTISARI}

Kebutuhan nangka terus meningkat baik untuk konsumsi rumah tangga, industri maupun sebagai tanaman konservasi. Hal ini memerlukan usaha peningkatan produktivitas melalui pengembangan dan pemeliharaan tanaman yang lebih intensif dan efisien. Salah satu aspek yang perlu diperhatikan dalam usaha peningkatan produktivitas adalah pembibitan tanaman. Penelitian bertujuan untuk mengetahui pengaruh perendaman benih nangka dalam air dan benih ditanam dengan berbagai posisi tanam terhadap pertumbuhan bibit nangka. Penelitian dilakukan di Laboratorium Hortikultura dan Rumah Kawat, Jurusan Budidaya Pertanian, Fakultas Pertanian Universitas Gadjah Mada, Yogyakarta pada bulan Februari sampai dengan Juli 2016. Penelitian menggunakan Rancangan Acak Lengkap (RAL) faktorial 2 x 5 dengan ulangan tiga kali. Faktor pertama adalah benih nangka ditanam dengan berbagai posisi, terdiri atas 2 level yaitu T1 (tengkurap) dan T2 (terlentang). Faktor kedua adalah perendaman benih nangka dalam air terdiri atas 5 level yaitu P1 
(direndam satu hari), P2 (direndam dua hari), P3 (tanpa perlakuan/kontrol), P4 (tanpa direndam satu hari) dan P5 (tanpa direndam dua hari). Pengamatan dilakukan terhadap gaya berkecambah, indeks vigor dan indeks vigor hipotetik. Hasil penelitian menunjukkan bahwa tidak terdapat interaksi antara faktor perendaman dengan posisi tanam benih terhadap pertumbuhan bibit. Benih nangka yang ditanam tengkurap memberikan pertumbuhan terbaik. Benih nangka yang direndam selama satu hari memberikan pengaruh terbaik terhadap pertumbuhan bibit.

Kata kunci: benih nangka, posisi tanam, perendaman, perkecambahan, indeks vigor

\section{PENDAHULUAN}

Tanaman nangka (Artocarpus heterophyllus Lamk.) merupakan salah satu jenis tanaman buah tropis yang multifungsi dan dapat ditanam di daerah tropis dengan ketinggian kurang dari 1.000 meter di atas permukaan laut yang berasal dari India Selatan. Tanaman nangka bisa dijadikan sebagai tanaman pagar dan tanaman penahan erosi dalam sistem konservasi, sehingga sangat potensial untuk dikembangkan. Selain itu, tanaman nangka dapat dijadikan sebagai tanaman penaung, tanaman pemecah angin serta ditanam secara polikultur dengan tanaman kelapa, durian, dan manga atau di fase-fase awal pertumbuhan dapat ditanam secara polikultur dengan tanaman pisang, jagung manis, dan kacang tanah (Elevitch and Manner, 2006).

Kebutuhan nangka terus meningkat baik untuk konsumsi rumah tangga, industri maupun sebagai tanaman konservasi. Pada tahun 2012 produksi nangka nasional mencapai 663,930 ton. Namun pada tahun 2013 mengalami penurunan menjadi 509,680 ton. Hal ini memerlukan usaha peningkatan produktivitas melalui pengembangan dan pemeliharaan tanaman yang lebih intensif dan efisien. Salah satu aspek yang perlu diperhatikan dalam usaha peningkatan produktivitas adalah pembibitan tanaman. Pembibitan yang baik diharapkan dapat menghasilkan tanaman yang mempunyai tingkat produktivitas dan kualitas yang tinggi (Siregar et al, 2000). Hal ini dapat dilakukan salah satunya dengan pemilihan benih yang berkualitas (mempunyai viabilitas tinggi) dan dapat dijadikan sebagai bahan tanam (pembibitan).

Benih nangka merupakan bagian yang paling sering digunakan sebagai bahan tanam (pembibitan). Pembibitan dilakukan dengan menyemai benih nangka dari buah nangka yang sudah matang. Sebelum disemai, benih nangka harus dibersihkan dari daging buah yang masih menempel. Pembersihan benih nangka dapat dilakukan dengan mencuci menggunakan air.

Benih dibagi menjadi dua kelompok berdasarkan kandungan air pada saat 
masak fisiologis yaitu benih rekalsitran dan ortodok. Benih nangka termasuk kedalam benih jenis rekalsitran. Benih rakalsitran merupakan benih tanaman yang pada saat masak fisiologis memiliki kandungan air di atas $20 \%$. Jika kandungan air diturunkan serta disimpan pada suhu udara rendah benih tersebut kehilangan daya tumbuh. Pada umumnya benih rekalsitran merupakan tanaman tahunan seperti kakao, durian, mangga, rambutan, kare. Benih ortodok merupakan benih tanaman yang pada saat masak fisiologis memiliki kandungan air di bawah 20\%. Jika kandungan air benih diturunkan serta disimpan pada suhu rendah benih tersebut tetap memiliki daya tumbuh yang tinggi. Sebagai contoh tanaman yang benihnya dikelompokkan kedalam benih ortodok seperti padi, jagung, kangkung dan kedelai.

Benih nangka akan mengalami kemunduran perkecambahan apabila kadar airnya turun dari $20 \%$, sehingga perlu dilakukan perlakuan agar perkecambahan benih nangka menjadi maksimal sebelum penanaman. Perlakuan pada benih dapat dilakukan dengan berbagai cara antara lain dengan cara mekanis, fisik maupun kimia. Perendaman merupakan salah satu upaya fisik yang dilakukan untuk memaksimalkan perkecambahan benih nangka. Pancaningtyas et al., (2014) menambahkan bahwa perendaman benih kakao menggunakan air dapat meningkatkan panjang radikula dalam proses perkecambahan.

Selain upaya fisik adapula upaya mekanis yang dapat dilakukan untuk memaksimalkan perkecambahan dengan mengatur posisi tanam benih. Pada pembibitan kakao. seperti yang dilaporkan Budianto dan Santoso (1999) bahwa pengaturan posisi tanam benih pada pembibitan tanaman sangat mempengaruhi pertumbuhan dan perkembangan awal bibit dan menentukan kualitas sistem perakaran. Berdasarkan hasil penelitian adanya pengaruh posisi tanam benih dan perendaman benih saat pembibitan pada tanaman tersebut, maka pengaturan posisi tanam benih dan pengaruh perendaman penting untuk dipelajari pada pembibitan tanaman nangka agar proses perkecambahan dan pertumbuhan bibit dapat berjalan baik.

Tujuan penelitian ini untuk mengetahui pengaruh perendaman air dan posisi tanam pada benih nangka serta mendapatkan interaksi perendaman air dan posisi tanam pada benih nangka pada pertumbuhan bibit yang baik. Manfaat yang diharapkan dari penelitian ini adalah diketahuinya perendaman benih nangka dan posisi tanam untuk mendapatkan bibit yang berkualitas. 


\section{BAHAN DAN METODE}

Penelitian dilakukan pada bulan Februari dan diakhiri bulan Juli 2016 dilaksanakan di Laboratorium Hortikultura dan Rumah Kawat, Jurusan Budidaya Pertanian, Fakultas Pertanian, Universitas Gadjah Mada, Yogyakarta. Peralatan yang digunakan dalam penelitian polibag ukuran $30 \times 30 \mathrm{~cm}$, kantong, ember, besek, pisau, penggaris, jangka sorong, spidol, oven dan timbangan digital.

Pengamatan yang dilakukan meliputi gaya berkecambah, indeks vigor, indeks vigor hipotetik berupa tinggi tanaman, diameter batang, jumlah daun, luas daun, dan bobot kering bibit. Rancangan percobaan dalam penelitian ini menggunakan Rancangan Acak Lengkap (RAL) faktorial dengan 3 ulangan. Faktor pertama posisi tanam benih nangka tengkurap dan posisi tanam benih nangka telentang, sedangkan factor kedua adalah benih nangka direndam air satu hari $(\mathrm{P} 1)$, benih nagka direndam dua hari (P2), benih nangka ditanam langsung (P3), benih nangka tanpa direndam satu hari (P4) dan benih nangka tanpa direndam satu hari (P5), untuk melihat interaksinya maka digunakan analisis varians, Apabila hasil yang diperoleh berbeda nyata, maka dilakukan uji Duncan's Multiple Range Test (DMRT) pada taraf 5\%.

\section{HASIL DAN PEMBAHASAN}

Berdasarkan hasil analisis varian menunjukkan bahwa tidak terdapat beda nyata pada faktor kondisi perendaman terhadap gaya berkecambah benih nangka. Tidak beda nyata juga terjadi pada faktor posisi benih terhadap gaya berkecambah benih nangka. Faktor kondisi perendaman dengan posisi benih nangka menunjukkan tidak terjadi interaksi terhadap gaya berkecambah.

Tabel 1. Rerata gaya berkecambah (\%) benih nangka pada berbagai posisi dan perendaman air

\begin{tabular}{lcccccc}
\hline \multirow{2}{*}{ Posisi Benih } & \multicolumn{7}{c}{ Perlakuan } \\
\cline { 2 - 7 } & P1 & P2 & P3 & P4 & P5 & Rerata \\
\hline Tengkurap & 97,78 & 100,00 & 91,11 & 86,67 & 88,89 & $92,89 \mathrm{p}$ \\
Telentang & 86,67 & 86,67 & 97,78 & 84,44 & 82,22 & $87,56 \mathrm{p}$ \\
\hline Rerata & $92,22 \mathrm{ab}$ & $93,33 \mathrm{ab}$ & $94,44 \mathrm{a}$ & $85,56 \mathrm{ab}$ & $85,55 \mathrm{~b}$ & $(-)$
\end{tabular}

Keterangan: (+) menunjukkan ada interaksi; rerata yang diikuti oleh huruf yang sama tidak berbeda nyata berdasarkan uji DMRT pada tingkat kepercayaan $5 \%$; data telah ditransformasi dalam bentuk $\sin (\sqrt{ } \times / 100)^{-1}$.

Berdasarkan hasil uji DMRT (Tabel 1) menunjukkan bahwa benih nangka tanpa perlakuan (kontrol) menunjukkan gaya berkecambah tertinggi (94,44\%) dibandingkan dengan perendaman dan tanpa perendaman. Gaya berkecambah benih nangka yang direndam selama satu dan dua hari tidak terdapat pengaruh dengan 
benih nangka tanpa perlakuan (kontrol). Hal ini juga terjadi pada benih nangka tanpa perendaman selama satu dan dua hari. Benih yang ditanam pada perlakuan kontrol dan pada benih yang tidak direndam dua hari menurunkan kemampuan untuk berkecambah diduga masih memiliki cadangan makanan yang optimal namun seiring berjalannya waktu pada benih tanpa perendaman cadangan makanan pada embrio tersebut berkurang dan mengering sehingga berpengaruh terhadap perkecambahan (Bewley and Black, 1994). Gaya berkecambah benih nangka terhadap posisi benih menunjukkan bahwa posisi benih yang tengkurap memiliki gaya berkecambah yang lebih tinggi (92,89\%) dibandingkan gaya berkecambah benih nangka dengan posisi terlentang (87,56\%).

Berdasarkan hasil analisis varian menunjukkan bahwa terdapat beda nyata pada faktor kondisi perendaman terhadap indeks vigor benih nangka. Beda nyata juga terjadi pada faktor posisi benih terhadap indeks vigor benih nangka, sedangkan tidak terjadi interaksi pada faktor kondisi perendaman dengan posisi benih nangka.

Tabel 2. Rerata pemunculan benih nangka di lapangan dari berbagai posisi dan perendaman air $(\%)$

\begin{tabular}{|c|c|c|c|c|c|c|}
\hline \multirow{2}{*}{$\begin{array}{l}\text { Posisi } \\
\text { Benih }\end{array}$} & \multicolumn{6}{|c|}{ Perlakuan } \\
\hline & P1 & $\mathrm{P} 2$ & P3 & $\mathrm{P} 4$ & $\mathrm{P} 5$ & Rerata \\
\hline Tengkurap & $68,89 a b$ & $75,56 \mathrm{a}$ & $60,00 \mathrm{bd}$ & $51,11 \mathrm{de}$ & $64,44 \mathrm{bc}$ & 64,00 \\
\hline Telentang & $64,44 \mathrm{bc}$ & $53,33 \mathrm{de}$ & $60,00 \mathrm{bd}$ & $55,56 \mathrm{ce}$ & 48,89 e & 56,44 \\
\hline Rerata & 66,67 & 64,44 & 60,00 & 53,33 & 56,67 & $60,22(+)$ \\
\hline
\end{tabular}

Berdasarkan tabel tersebut, perlakuan benih nangka yang tengkurap (T1) berkecambah lebih serempak dibandingkan perlakuan benih nangka yang terlentang (T2) dengan nilai CV sebesar 64,00 \%, sedangkan nilai CV perlakuan benih terlentang (T2) \%, Benih nangka yang direndam air selama dua hari dengan posisi tanam benih tengkurap memberikan hasil keserempakan tumbuh paling besar mencapai $75,56 \%$ pada hari ke-15 hal ini menunjukkan bahwa apabila benih nangka dilakukan perendaman selama dua hari dan ditanam dengan posisi tengkurap maka kemampuan benih tersebut untuk tumbuh dan berkembang dilingkungan optimal maupun suboptimal akan lebih tinggi yaitu mendekati $100 \%$.

Berdasarkan hasil analisis varian menunjukkan bahwa tidak terdapat beda nyata pada faktor kondisi perendaman terhadap jumlah daun benih nangka. Tidak beda nyata juga terjadi pada faktor posisi benih terhadap jumlah daun benih nangka. Faktor kondisi perendaman dengan posisi benih nangka juga tidak terjadi interaksi 
terhadap jumlah daun. Hal ini berarti jumlah daun bibit nangka tidak dipengaruhi oleh faktor kondisi perendaman dengan posisi peletakkan benih.

Tabel 3. Rerata jumlah daun (lembar) bibit nangka pada berbagai posisi dan perendaman air

\begin{tabular}{|c|c|c|c|c|c|c|}
\hline \multirow{2}{*}{ Posisi Benih } & \multicolumn{6}{|c|}{ Perlakuan } \\
\hline & $\mathrm{P} 1$ & $\mathrm{P} 2$ & P3 & $\mathrm{P} 4$ & P5 & Rerata \\
\hline Tengkurap & 4,80 & 4,87 & 4,87 & 4,40 & 5,40 & $4,87 p$ \\
\hline Telentang & 4,73 & 4,80 & 5,00 & 4,60 & 4,67 & $4,76 p$ \\
\hline Rerata & $4,76 \mathrm{a}$ & $4,83 a$ & $4,93 \mathrm{a}$ & $4,50 \mathrm{a}$ & $5,03 a$ & $(-)$ \\
\hline
\end{tabular}

Berdasarkan hasil uji DMRT (Tabel 3) menunjukkan bahwa benih nangka tanpa perendaman selama dua hari memiliki jumlah daun terbanyak $(5,03)$. Pada semua kondisi perendaman satu dan dua hari dan tanpa perendaman satu dan dua hari tidak ada beda nyata satu sama lain. Posisi benih nangka tengkurap memiliki jumlah daun yang lebih banyak $(4,87)$ sedangkan posisi benih nangka yang terlentang memiliki jumlah daun $(4,76)$ dan tidak berbeda nyata satu sama lain. Benih yang ditanam dengan posisi tengkurap akan tumbuh lebih cepat, sehingga jumlah daun yang dihasilkan lebih banyak. Pada posisi tanam benih tengkurap dan tanpa perendaman dua hari meningkatkan hasil jumlah daun begitu pula terjadi pada posisi benih telentang yang lansung ditanam. Daun berperan sebagai tempat proses fotosintesis yang menghasilkan energi. Ketersediaan energi yang cukup yang terdapat dalam bagian tanaman (daun) akan mendorong pembentukan kalus yang cukup banyak, sehingga berdampak pada jumlah daun yang dihasilkan (Suryadi, 2009).

Berdasarkan hasil analisis varian menunjukkan bahwa terdapat beda nyata pada faktor kondisi perendaman terhadap luas daun benih nangka. Tidak beda nyata terjadi pada faktor posisi benih terhadap luas daun benih nangka. Faktor kondisi perendaman dengan posisi benih nangka tidak menunjukkan adanya interaksi terhadap luas daun. Hal ini berarti luas daun bibit nangka tidak dipengaruhi oleh faktor kondisi perendaman dengan posisi peletakkan benih.

Tabel 4. Rerata luas daun $\left(\mathrm{cm}^{2}\right)$ bibit nangka pada berbagai posisi dan perendaman air

\begin{tabular}{lcccccc}
\hline \multirow{2}{*}{ Posisi Benih } & \multicolumn{7}{c}{ Perlakuan } \\
\cline { 2 - 7 } & P1 & P2 & P3 & P4 & P5 & Rerata \\
\hline Tengkurap & 209,79 & 231,77 & 140,51 & 194,93 & 203,36 & $196,07 \mathrm{p}$ \\
Telentang & 210,31 & 212,92 & 149,04 & 183,57 & 183,45 & $187,86 \mathrm{p}$ \\
\hline Rerata & $210,05 \mathrm{a}$ & $222,34 \mathrm{a}$ & $144,77 \mathrm{~b}$ & $189,25 \mathrm{a}$ & $193,40 \mathrm{a}$ & $(-)$ \\
\hline Keterangan: & $\begin{array}{l}\text { (-) } \\
\text { tidak benunjukkan tidak ada interaksi; rerata yang diikuti }\end{array}$ \\
& & &
\end{tabular}


Berdasarkan hasil uji DMRT (Tabel 4) menunjukkan bahwa benih nangka dengan kondisi perendaman selama dua hari memiliki luas daun tertinggi $(222,34$ $\mathrm{cm}^{2}$ ). Luas daun benih nangka yang direndam selama satu dan dua hari menunjukkan bahwa ada pengaruh dengan benih tanpa perlakuan (kontrol). Benih nangka tanpa perendaman selama satu dan dua hari juga menunjukkan adanya pengaruh dengan benih nangka tanpa perlakuan (kontrol). Posisi tanam benih tengkurap dan terlentang yang direndam satu hari maupun dua hari dapat meningkatkan terhadap luas daun kemudian hal tersebut terjadi pada posisi benih tengkurap tanpa perendaman dua hari. Posisi benih nangka yang tengkurap memiliki luas daun yang lebih tinggi $\left(196,07 \mathrm{~cm}^{2}\right)$, sedangkan posisi benih nangka yang terlentang memiliki luas daun $\left(187,86 \mathrm{~cm}^{2}\right)$. Posisi benih nangka tengkurap dan terlentang tidak menunjukkan adanya beda nyata. Pertumbuhan bibit pada kedua posisi tanam memiliki kemampuan tumbuh yang sama baik. Namun pada benih yang ditanam pada dengan posisi tengkurap mempunyai luas daun yang lebih tinggi, hal ini disebabkan pertumbuhan akar pada benih yang ditanam tengkurap tidak terjadi pembelokan akar pada saat berkecambah sehingga proses pembentukan daun lebih cepat dibandingkan benih yang ditanam terlentang.

Berdasarkan hasil analisis varian menunjukkan bahwa terdapat beda nyata pada faktor kondisi perendaman terhadap tinggi bibit nangka. Tidak beda nyata terjadi pada faktor posisi benih terhadap tinggi bibit nangka. Faktor kondisi perendaman dengan posisi benih nangka menunjukkan tidak ada interaksi terhadap tinggi bibit. Hal ini berarti tinggi bibit nangka tidak dipengaruhi oleh faktor kondisi perendaman dengan posisi peletakkan benih.

Tabel 5. Rerata tinggi bibit $(\mathrm{cm})$ nangka pada berbagai posisi dan perendaman air.

\begin{tabular}{lcccccc}
\hline \multirow{2}{*}{ Posisi Benih } & \multicolumn{7}{c}{ Perlakuan } \\
\cline { 2 - 7 } & P1 & P2 & P3 & P4 & P5 & Rerata \\
\hline Tengkurap & 31,10 & 32,15 & 27,87 & 30,29 & 37,21 & $31,73 \mathrm{p}$ \\
Telentang & 30,21 & 31,04 & 28,68 & 30,86 & 34,33 & $31,02 \mathrm{p}$ \\
\hline Rerata & $30,66 \mathrm{~b}$ & $31,60 \mathrm{ab}$ & $28,28 \mathrm{~b}$ & $30,58 \mathrm{~b}$ & $35,77 \mathrm{a}$ & $(-)$
\end{tabular}

Keterangan: (-) menunjukkan tidak ada interaksi; rerata yang diikuti oleh huruf yang sama tidak berbeda nyata berdasarkan uji DMRT pada tingkat kepercayaan $5 \%$.

Berdasarkan hasil uji DMRT (Tabel 5) menunjukkan bahwa benih nangka dengan kondisi perendaman terbuka selama dua hari memiliki tinggi bibit paling tinggi $(35,77 \mathrm{~cm})$. Tinggi bibit benih nangka yang direndam selama satu dan dua hari menunjukkan tidak ada pengaruh dengan tinggi bibit tanaman nangka tanpa perlakuan (kontrol). Pada tinggi bibit benih nangka tanpa perendaman selama dua hari menunjukkan adanya pengaruh dengan benih tanpa perlakuan (kontrol), 
sedangkan tinggi bibit benih tanpa perendaman selama satu hari tidak menunjukkan adanya pengaruh nyata. Posisi benih nangka yang tengkurap memiliki tinggi bibit yang lebih tinggi $(31,73 \mathrm{~cm})$, sedangkan posisi benih nangka yang terlentang memiliki tinggi bibit $(31,02 \mathrm{~cm})$.

Berdasarkan hasil analisis varian menunjukkan bahwa terdapat beda nyata pada faktor kondisi perendaman terhadap diameter batang bibit nangka. Tidak beda nyata terjadi pada faktor posisi benih terhadap diameter batang bibit nangka. Faktor kondisi perendaman dengan posisi benih nangka menunjukkan tidak ada interaksi terhadap diameter batang bibit. Hal ini berarti diameter batang bibit nangka tidak dipengaruhi oleh faktor kondisi perendaman dengan posisi peletakkan benih.

Tabel 6. Rerata diameter batang $(\mathrm{mm})$ bibit nangka pada berbagai posisi dan perendaman air

\begin{tabular}{lcccccc}
\hline \multirow{2}{*}{ Posisi Benih } & \multicolumn{7}{c}{ Perlakuan } \\
\cline { 2 - 7 } & $\mathrm{P} 1$ & $\mathrm{P} 2$ & $\mathrm{P} 3$ & $\mathrm{P} 4$ & $\mathrm{P} 5$ & Rerata \\
\hline Tengkurap & 5,32 & 5,40 & 4,52 & 5,25 & 5,68 & $5,23 \mathrm{p}$ \\
Telentang & 5,55 & 5,21 & 4,80 & 5,59 & 6,00 & $5,43 \mathrm{p}$ \\
\hline Rerata & $5,44 \mathrm{a}$ & $5,31 \mathrm{a}$ & $4,66 \mathrm{~b}$ & $5,42 \mathrm{a}$ & $5,84 \mathrm{a}$ & $(-)$
\end{tabular}

Keterangan: (-) menunjukkan tidak ada interaksi; rerata yang diikuti oleh huruf yang sama tidak berbeda nyata berdasarkan uji DMRT pada tingkat kepercayaan $5 \%$.

Berdasarkan hasil uji DMRT (Tabel 4.7) menunjukkan bahwa benih nangka tanpa perendaman selama dua hari memliki diameter batang tertinggi $(5,84 \mathrm{~mm})$. Diameter batang benih nangka yang direndam selama satu dan dua hari menunjukkan adanya pengaruh dengan benih tanpa perlakuan (kontrol). Begitu juga pada benih tanpa perendaman selama satu dan dua hari menunjukkan adanya pengaruh dengan benih tanpa perlakuan (kontrol). Posisi benih nangka yang terlentang memiliki diameter batang yang lebih tinggi $(5,43 \mathrm{~mm})$, sedangkan posisi benih nangka yang tengkurap memiliki diameter batang $(5,23 \mathrm{~mm})$. Posisi benih nangka tengkurap dan terlentang tidak menunjukkan adanya pengaruh nyata. Pada perlakuan perendaman air selama satu dan dua hari dan tanpa perendaman selama satu dan dua hari dapat meningkatkan diameter pada bibit.

Berdasarkan hasil analisis varian menunjukkan bahwa terdapat beda nyata pada faktor kondisi perendaman terhadap berat kering bibit nangka. Tidak beda nyata terjadi pada faktor posisi benih terhadap berat kering bibit nangka. Faktor kondisi perendaman dengan posisi benih nangka juga menunjukkan tidak ada interaksi terhadap berat kering bibit. Hal ini berarti berat kering bibit nangka tidak dipengaruhi oleh faktor kondisi perendaman dengan posisi peletakkan benih. 
Asiyah Atdwiyani et al., / Vegetalika. 2017. 6(1): 1-11

Tabel 7. Rerata berat kering bibit ( $\mathrm{g}$ ) benih nangka pada berbagai posisi dan perendaman air

\begin{tabular}{lcccccc}
\hline \multirow{2}{*}{ Posisi Benih } & \multicolumn{7}{c}{ Perlakuan } \\
\cline { 2 - 7 } & $\mathrm{P} 1$ & $\mathrm{P} 2$ & $\mathrm{P} 3$ & $\mathrm{P} 4$ & $\mathrm{P} 5$ & Rerata \\
\hline Tengkurap & 12,71 & 12,00 & 7,77 & 11,95 & 13,11 & $11,51 \mathrm{p}$ \\
Telentang & 12,54 & 9,83 & 8,29 & 11,62 & 11,49 & $10,75 \mathrm{p}$ \\
\hline Rerata & $12,63 \mathrm{a}$ & $10,91 \mathrm{ab}$ & $8,03 \mathrm{~b}$ & $11,78 \mathrm{a}$ & $12,30 \mathrm{a}$ & $(-)$ \\
\hline Keterangan: & $\begin{array}{l}\text { (-) } \\
\text { tidak benunjukkan tidak ada interaksi; rerata yang diikuti }\end{array}$ & oleh huruf & yang sama \\
& tida nyata berdasarkan uji DMRT pada tingkat kepercayaan $5 \%$.
\end{tabular}

Berdasarkan hasil uji DMRT (Tabel 7) menunjukkan bahwa benih nangka dengan kondisi perendaman selama satu hari memiliki berat kering bibit paling tinggi $(12,63 \mathrm{~g})$. Berat kering bibit benih nangka yang direndam selama satu hari memiliki pengaruh dengan benih tanpa perlakuan (kontrol), sedangkan benih nangka yang direndam selama dua hari tidak menunjukkan adanya pengaruh dengan benih tanpa perlakuan (kontrol). Posisi tanam benih tengkurap dan tanpa perendaman dua hari dapat meningkatkan berat kering bibit, kondisi tersebut juga terdapat pada posisi tanam benih tengkurap dan terlentang yang direndam satu hari, kemudiaan terdapat pada posisi tanam benih tengkurap yang direndam dua hari. Benih yang direndam dengan air menyebabkan kulit benih nangka menjadi lebih lunak, sehingga masuknya air ke dalam benih lebih mudah dan menjadikan bibit lebih cepat tumbuh dari pada benih tanpa perendaman. Bibit yang lebih cepat tumbuh memiliki vigoritas yang tinggi sehingga pertumbuhan dan kemampuan menyerap unsur hara menjadi semakin baik, sehingga apabila bibit dikeringkan akan menghasilkan senyawa organik kering yang merupakan hasil sintesis dari tanaman. Berat kering bibit nangka tanpa perendaman selama satu dan dua hari menunjukkan adanya beda nyata dengan benih tanpa perlakuan (kontrol).

Posisi benih nangka yang tengkurap memiliki berat kering bibit yang lebih tinggi $(11,51 \mathrm{~g})$, sedangkan posisi benih nangka yang terlentang memiliki berat kering bibit $(10,75 \mathrm{~g})$. Posisi benih nangka terlentang dan tengkurap tidak berbeda nyata satu sama lain. Pertumbuhan bibit pada kedua posisi memiliki kemampuan tumbuh sama baik. Namun benih yang ditanam dengan posisi tengkurap mempunyai bobot kering lebih tinggi, hal ini disebabkan pertumbuhan akar benih yang ditanam tengkurap tidak terjadi pembelokan akar pada saat berkecambah sehingga menjadikan bibit lebih cepat tumbuh.

Penelitian ini menggunakan jumlah daun, luas daun, tinggi bibit, diameter batang dan berat kering bibit sebagai komponen tumbuh bibit untuk perhitungan indeks vigor hipotetik. Indeks vigor hipotetik merupakan hasil perhitungan perbandingan semua komponen tumbuh bibit yang dibandingkan dengan umur bibit. 
Bibit yang mempunyai indeks vigor hipotetik lebih besar menandakan pertumbuhan bibit tersebut lebih cepat, karena bertambahnya berat kering bibit lebih besar.

Berdasarkan hasil analisis varian menunjukkan bahwa tidak terdapat beda nyata pada faktor kondisi perendaman terhadap indeks vigor hipotetik benih nangka. Tidak beda nyata juga terjadi pada faktor posisi benih terhadap indeks vigor hipotetik benih nangka. Faktor kondisi perendaman dengan posisi benih nangka menunjukkan tidak terdapat interaksi terhadap indeks vigor hipotetik.

Tabel 8. Rerata indeks vigor hipotetik benih nangka pada berbagai posisi tanam dan perendaman air

\begin{tabular}{lcccccc}
\hline \multirow{2}{*}{ Posisi Benih } & \multicolumn{7}{c}{ Perlakuan } \\
\cline { 2 - 7 } & $\mathrm{P} 1$ & $\mathrm{P} 2$ & $\mathrm{P} 3$ & $\mathrm{P} 4$ & $\mathrm{P} 5$ & Rerata \\
\hline Tengkurap & 3,6 & 3,62 & 3,31 & 3,54 & 3,69 & $3,55 \mathrm{p}$ \\
Telentang & 3,61 & 3,54 & 3,38 & 3,56 & 3,59 & $3,54 \mathrm{p}$ \\
\hline Rerata & $3,6 \mathrm{a}$ & $3,58 \mathrm{a}$ & $3,35 \mathrm{~b}$ & $3,55 \mathrm{a}$ & $3,64 \mathrm{a}$ & $(-)$ \\
\hline
\end{tabular}

Keterangan: (-) menunjukkan tidak ada interaksi; rerata yang diikuti oleh huruf yang sama tidak berbeda nyata berdasarkan uji DMRT pada tingkat kepercayaan $5 \%$.

Berdasarkan hasil uji DMRT (Tabel 8) menunjukkan bahwa benih nangka dengan kondisi perendaman selama satu hari memiliki indeks vigor hipotetik tertinggi $(3,6)$. Indeks vigor hipotetik benih nangka yang direndam selama satu dan dua hari menunjukkan ada pengaruh terhadap benih nangka tanpa perlakuan (kontrol). Begitu juga pada benih nangka tanpa perendaman menunjukkan bahwa ada pengaruh dengan benih nangka tanpa perlakuan (kontrol).

Posisi benih tengkurap dengan terlentang tidak menunjukkan pengaruh nyata meskipun indeks vigor hipotetik pada benih yang tengkurap yang lebih tinggi $(3,55)$ dari pada posisi benih yang terlentang $(3,54)$. Posisi benih yang tengkurap memudahkan proses masuknya air ke dalam benih sehingga benih yang diletakkan secara tengkurap memiliki indeks vigor hipotetik lebih tinggi dibandingkan benih yang diletakkan secara terlentang. Pada perlakuan perendaman selama satu dan dua hari dan tanpa perendaman satu dan dua hari dapat meningkatkan pertumbuhan bibit.

Hasil percobaan secara umum menjelaskan bahwa pengaturan posisi tanam dan perlakuan perendaman dan tidak direndam benih hanya berpengaruh pada proses perkecambahan benih nangka, namun tidak berpengaruh pada pertumbuhan dan perkembangan bibit selanjutnya. Hal ini disebabkan karena kelangsungan pertumbuhan bibit nangka lebih dipengaruhi oleh ketersediaan unsur pada media tanam, sedangkan proses perkecambahan dipengaruhi oleh cadangan makanan yang ada di dalam benih. Hal ini sejalan dengan pendapat Sumiasri dan 
Asiyah Atdwiyani et al., / Vegetalika. 2017. 6(1): 1-11

Setyowati (2006) menyatakan bahwa perkecambahan pada tanaman lebih dipengaruhi oleh ketersediaan makanan dalam benih. Apabila persediaan cadangan makanan (karbohidrat, lemak, protein, dan mineral) di dalam benih habis maka akan berpengaruh terhadap pertumbuhan tanaman selanjutnya.

\section{KESIMPULAN}

1. Tidak terdapat interaksi antara faktor perendaman dan posisi tanam benih terhadap pertumbuhan bibit.

2. Perendaman benih nangka selama satu hari memberikan pengaruh paling baik terhadap pertumbuhan bibit.

3. Penanaman benih nangka dengan posisi tengkurap memberikan pengaruh paling baik terhadap pertumbuhan bibit.

\section{DAFTAR PUSTAKA}

Bewley, J.D. and M. Black. 1994. Seeds. Springer, United States.

Budianto, A., B.B. Santoso. 1999. Pengaruh posisi benih terhadap pertumbuhan dan perkembangan bibit Nagasari (Mesua ferrea L.). J. Agroteksos. 4(3):56-60.

Elevitch, C.R., and H.I. Manner. 2006. Artocarpus heterophyllus (jackfruit). Species Profiles for Pacific Island Agroforestry. Permanent Agriculture Resources (PAR), Holualoa, Hawai'i. <http://www.traditionaltree.org>. Diakses pada tanggal 31 Mei 2016.

Pancaningtyas, S. Santoso, T.I., dan Sudarsianto. 2014. Studi perkecambahan benih kakao melalui metode perendaman. Pelita Perkebunan. 30(3): 2014, 190-197.

Siregar, T.H., S. Riyadi, L. Nuraeni. 2000. Budidaya pengolahan dan pemasaran coklat. Penebar Swadaya, Jakarta.

Sumiasri, N. dan Setyowati, N. 2006. Pengaruh beberapa media pada pertumbuhan bibit eboni (Diospyros celebica Bakh) melalui perbanyakan biji. Biodiversitas. Vol. 7 no. 3. Hal: 260-263.

Suryadi, R. 2009. Pengaruh jumlah tunas dan jumlah daun terhadap keberhasilan penyambungan jambu mete (Anacardium occidentale) di lapangan. Buletin Littro. Vol. 20 No. 1, 2009, 41 - 49. 